\title{
Renewable energy Sector in Gujarat, India
}

\author{
Zahira Tabassum ${ }^{1}$, Dr.Chandrashekhar Shastry ${ }^{2}$ \\ ${ }^{I}$ Department of Electronics \& Communication Engineering, HKBKCE \\ ${ }^{2}$ Centre for Distance education and Virtual Learning (CDEVL), Jain University
}

\begin{abstract}
Excessive use of traditional energy sources such as fossil fuels has resulted in significant environmental deterioration. India is one of the world's fastest-growing energy consumers, and it is making continual efforts to increase renewable energy generation. The use of renewable energy sources to generate electricity is expanding every day. Renewable energy integration with existing power systems is a difficult endeavour that necessitates strategy and development. Climate-friendly energy systems will result from the use of renewable energy sources in power generation, as they lower CO2 emissions caused by fossil fuels used in conventional power generation. This research looks at a renewable energy scenario using Gujarat as a case study, which is a leader in renewable energy generation. The policies taken by the Gujarat government to increase renewable energy's participation in the energy mix, as well as the challenges and potential solutions for boosting the deployment of renewable energy sources across Gujarat, are discussed. This study can be used as a guide for policymakers and researchers in other states and around the world who want to boost the renewable energy share.
\end{abstract}

Keywords: CO2 Emissions, Policies, Targets, Challenges

\section{INTRODUCTION}

India is one of the countries having a significant amount of renewable energy output. Renewable energy sources provide for 38 percent of India's installed electrical generation, or $136 \mathrm{GW}$ out of $373 \mathrm{GW}$. India has set a goal of using non-fossil fuels to generate $40 \%$ of its total electricity. India is implementing one of the world's largest and most ambitious renewable energy expansion plans. India now ranks third in the world in terms of energy consumption due to its rising level of life and population. Because fossil fuels are depleting and causing more pollution, which contributes to global warming, and because energy demand is increasing every day, energy production from renewable energy resources has become the greatest option in the current situation. Table 1 shows the total installed grid interactive renewable power capacity in India as of February 28, 2021 and targeted renewable generation by 2022. Figure 1 shows the percentage share of total installed grid interactive renewable power capacity in India as of February 28, 2021 (excluding large hydro).

Table. 1. Installed capacity vs. Target

\begin{tabular}{|l|l|l|}
\hline \multicolumn{1}{|c|}{ Source } & \multicolumn{1}{|c|}{$\begin{array}{c}\text { Total installed capacity } \\
(\mathrm{MW})\end{array}$} & \multicolumn{1}{|c|}{$\begin{array}{c}\text { 2022 target } \\
(\mathrm{MW})\end{array}$} \\
\hline Solar power & $38,794 \quad$ & 100,000 \\
\hline Wind power & 38,684 & 60,000 \\
\hline Bio Mass Power & $10,145.92$ & 10,000 \\
\hline Waste to power & 168.64 & \\
\hline Small hydro power & $4,739.97$ & 5,000 \\
\hline Total & $\mathbf{8 9 , 2 2 9 . 4 2}$ & $\mathbf{1 7 5 , 0 0 0}$ \\
\hline
\end{tabular}




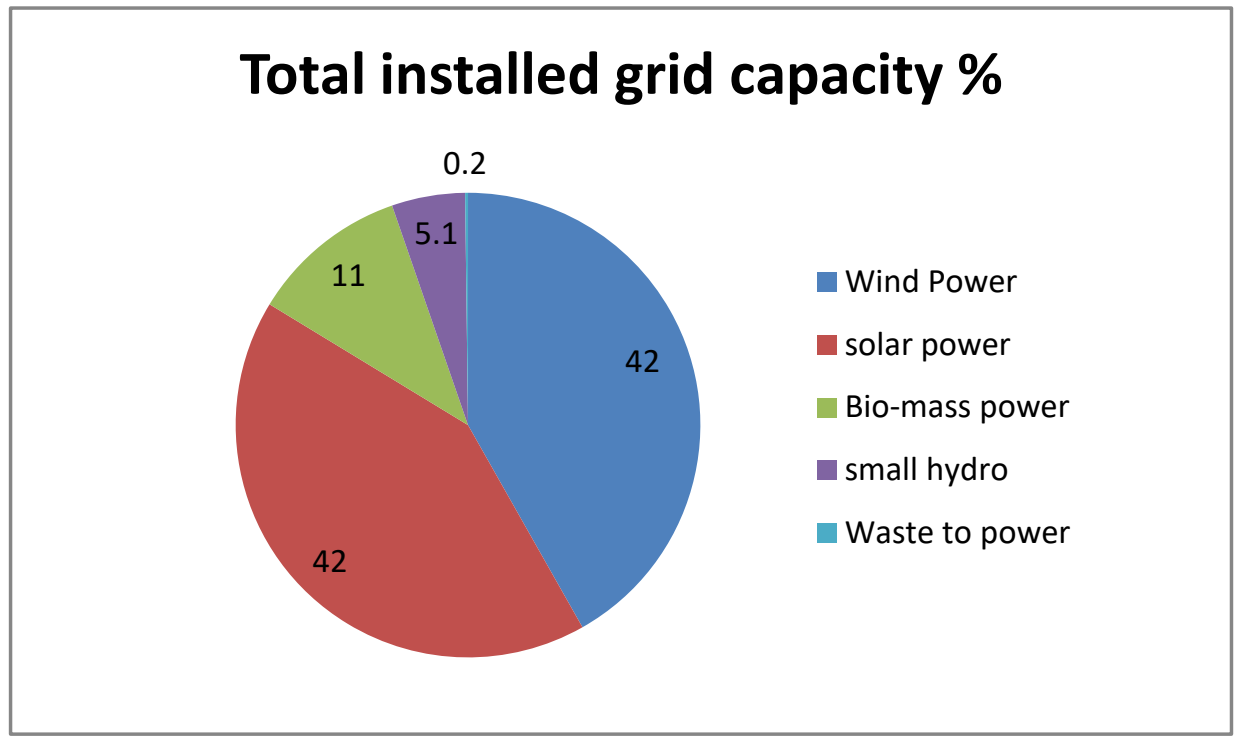

Fig.1. Total installed grid interactive renewable power capacity

Fig. 2 depicts top 5 states renewable generation as on 31.03.2021.Karnataka leads in total installed capacity of renewable power generation followed by Tamil Nadu, Gujarat, Rajasthan and Andhra Pradesh. Karnataka is the highest producer of solar power followed by Rajasthan, whereas Tamil Nadu is highest producer of Wind power followed by Gujarat.

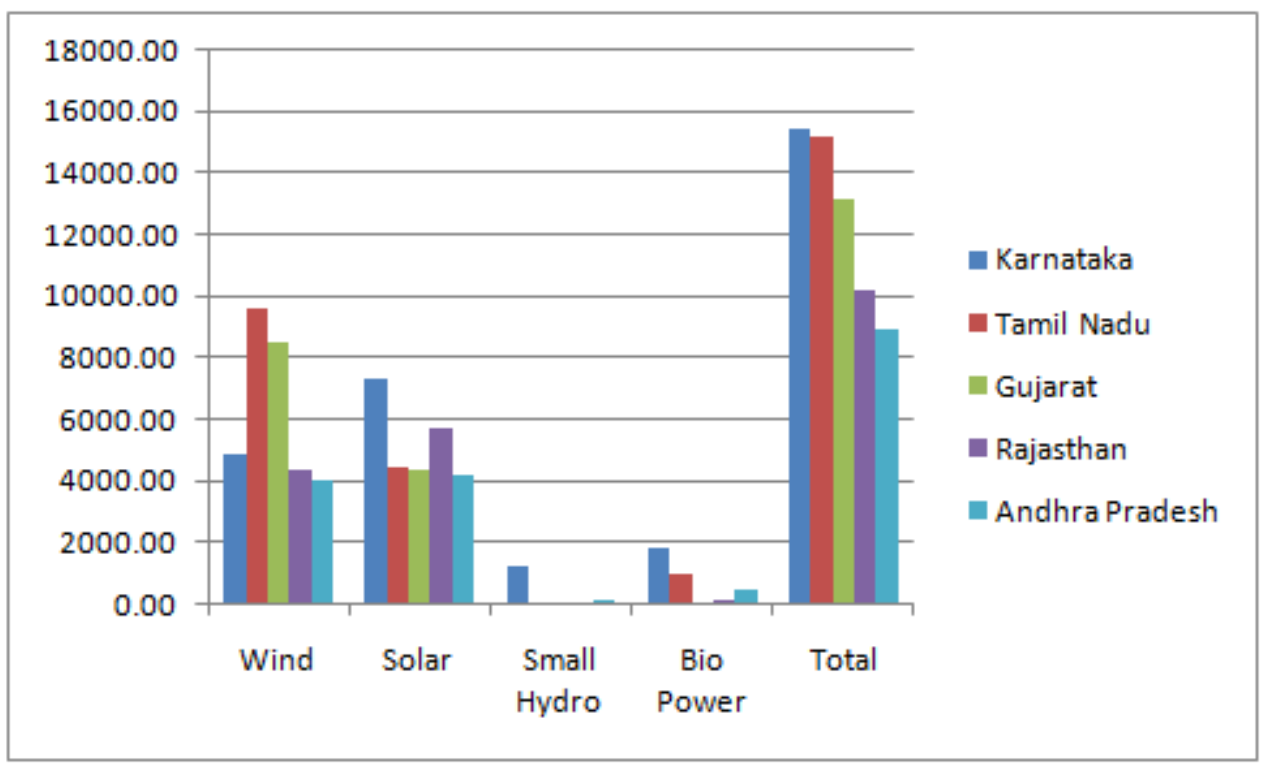

Fig.2 Renewable generation in top 5 states as on 31.03.2021

In this paper, a case study on the state of Gujarat is considered as it leads the renewable energy movement in India as on today. The aim of this study is to have an insight of current energy scenario of Gujarat including the renewable energy resources and its utility so far that has contributed in the socio-economic development[1]. Section II presents the salient features of the Gujarat grid and the policies adopted by the state to enhance renewable power generation. Section III highlights the growth in wind power generation and policies adopted to enhance the generation. Section IV highlights the growth in solar power generation and policies adopted to enhance the generation. Section V presents the issues and challenges faced and measures adopted by the state government to meet the challenges.

\section{GUJARAT GRID}

Gujarat is a state on the western coast of India with a long coastline of 1,600 km most of which lies on the Kathiawar peninsula with a population of 60.4 million. It is the fifthlargest Indian state by area and the ninth-largest state by population. With a gross state 
domestic product (GSDP) of ₹ 16.5 trillion Gujarat is ranked fifth largest state economics in India, Gujarat ranks 21st among Indian states in human development index. The state traditionally has low unemployment and is widely considered one of the most industrially developed states of India and a manufacturing hub. Gujarat is a state with surplus electricity[12] .Gujarat is the first state in India to achieve 100\% electrification providing $24 * 7$ electricity access with lowest AT\&C losses among other states.

Among all the states of India, Gujarat, with latitude of $23^{\circ} \mathrm{N}$ and longitude of $72 \circ \mathrm{E}$ is one of the fastest advancing states with an area of $196,024 \mathrm{~km}^{2}$. Due to its geographical location, Gujarat is one of the most promising states in India in regard to RE potentialities and current RE generation capacity as it is higher than most other states in India.

Energy is widely acknowledged as one of the most critical inputs for economic progress and human development. It's been identified as one of the most important drivers of rapid growth and poverty reduction. The state's installed power generation capacity has grown from 315 megawatts in 1960-61 to 28277 megawatts in 2019-2020. (as on 31.03.20). GSECL's installed capacity (as of 31.03.20) is 6776 MW. In the 2018-19 fiscal year, Gujarat's per capita energy usage was 2208 KWh.Fig. 3 shows the installed capacity sector wise as on 31/3/2020.

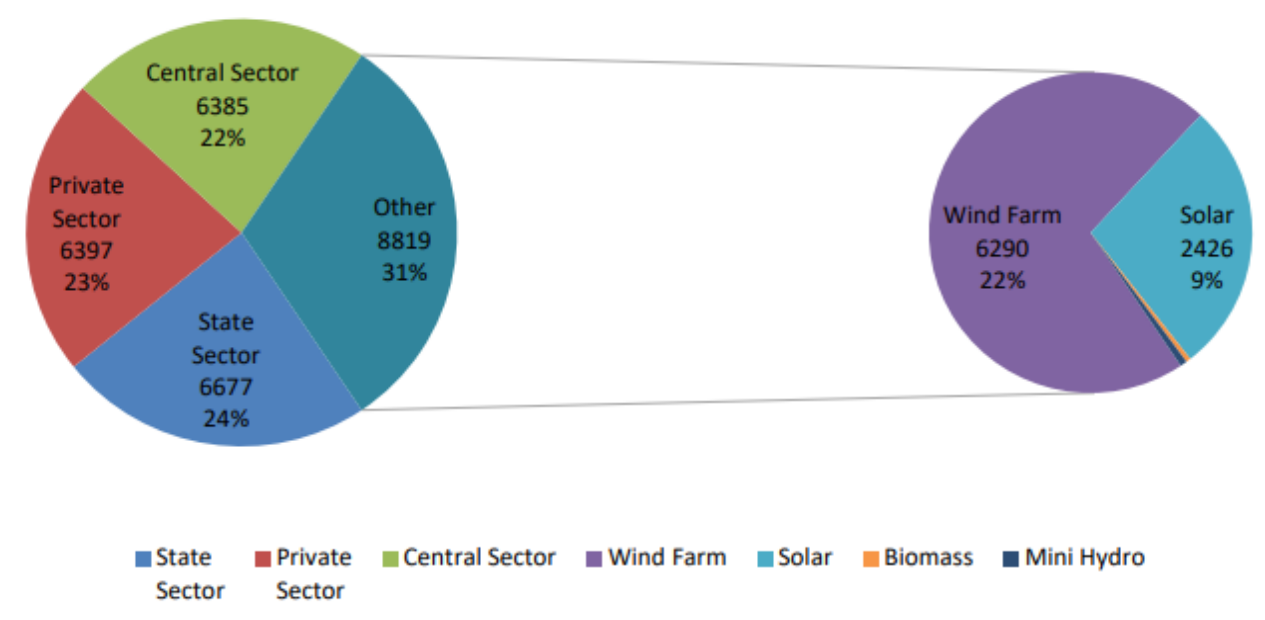

Fig.3. Sector wise installed capacity in MW[3]

Thermal power sources dominate Gujarat's present electricity mix. 15.8 GW of coal-fired capacity and $6.6 \mathrm{GW}$ of gas-fired capacity make up the $22.3 \mathrm{GW}$ of thermal capacity. In Gujarat, this accounts for 69 percent of total capacity and 81 percent of generating. Due to a lack of sufficient in-state "black" coal mining capacity, more than $90 \%$ of Gujarat's coalfired power plants rely on either expensive imported seaborne coal or imported coal from other states.Fig.4 indicates fuel wise installed capacity as on 31-03-2020.

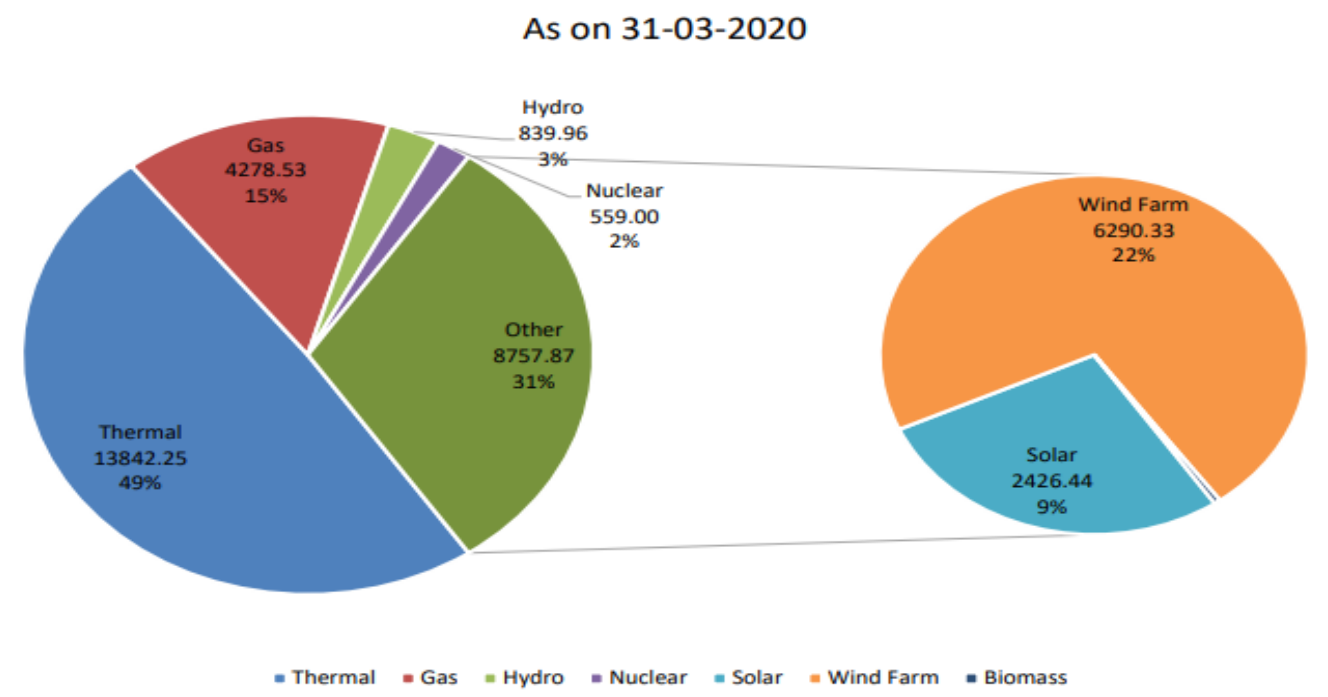

Fig.4 Fuel wise installed capacity in MW[3] 
The sector wise energy generation during the last 8 years is depicted in Table 1.From the table it can be observed that there is a consistent increase in the generation of power using renewable energy sources i.e. Wind and Solar and also a consistent increase in the generation of power.

Table 1. Sector wise generation in MUs

\begin{tabular}{|l|l|l|c|c|c|c|c|c|}
\hline Year & GSECL & $\begin{array}{c}\text { Private } \\
\text { Sector }\end{array}$ & $\begin{array}{c}\text { Central } \\
\text { Sector }\end{array}$ & $\begin{array}{c}\text { Wind } \\
\text { Energy }\end{array}$ & Solar & Biomass & $\begin{array}{c}\text { Mini } \\
\text { Hydro }\end{array}$ & $\begin{array}{c}\text { Total } \\
\text { MUs }\end{array}$ \\
\hline $2012-13$ & 23631 & 42682 & 14754 & 5436 & 1145 & 43 & 32 & 87723 \\
\hline $2013-14$ & 15850 & 46202 & 17440 & 5289 & 1369 & 24 & 47 & 86221 \\
\hline $2014-15$ & 21415 & 48721 & 19276 & 5660 & 1475 & 40 & 49 & 96636 \\
\hline $2015-16$ & 19277 & 53219 & 22480 & 6447 & 1645 & 25 & 45 & 103137 \\
\hline $2016-17$ & 16254 & 51024 & 27500 & 7720 & 1738 & 12 & 36 & 104285 \\
\hline $2017-18$ & 23683 & 42518 & 32776 & 9636 & 2048 & 33 & 45 & 110739 \\
\hline $2018-19$ & 25088 & 41471 & 41623 & 11194 & 2408 & 75 & 100 & 121959 \\
\hline
\end{tabular}

During the fiscal year 2020, the peak power demand in the Indian state of Gujarat increased by over eight percent as compared to the previous fiscal year. During this period, the nation's peak power demand was over 182 thousand megawatts. Fig.5. Shows the year on year change in peak power demand across Gujarat in India between financial year 2016 and 2020

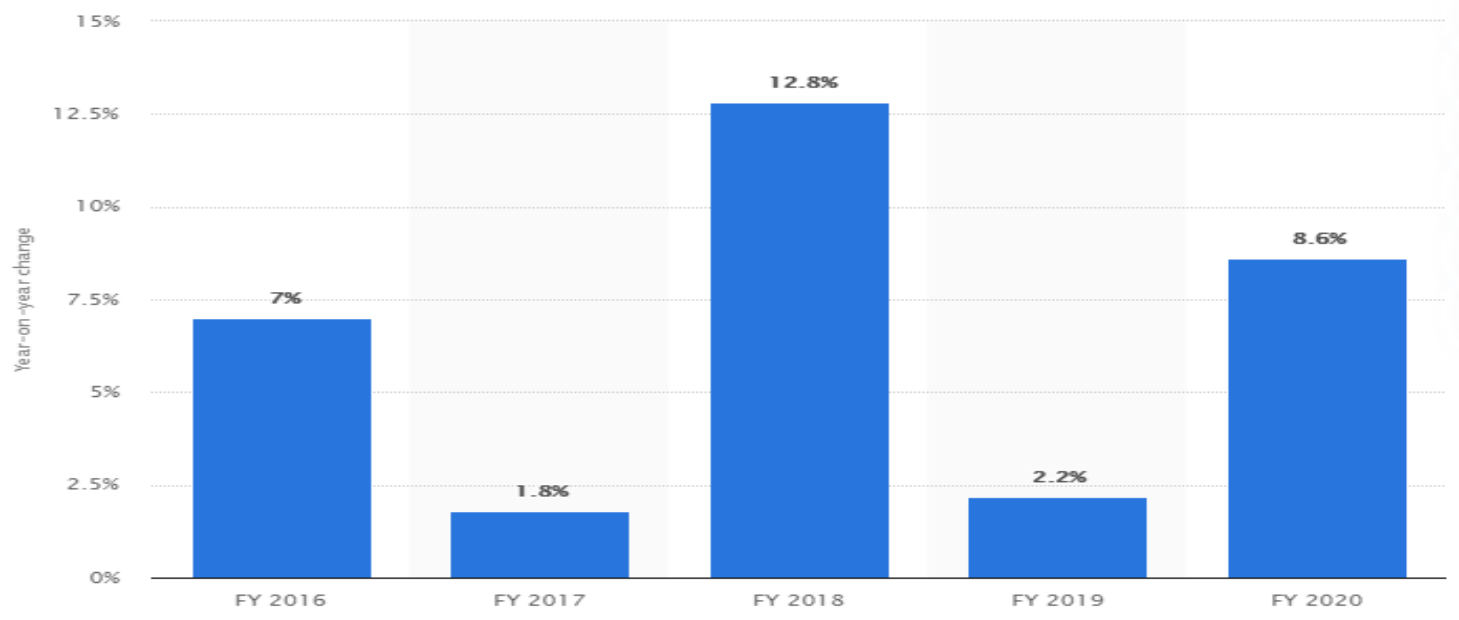

Fig.5.Change in peak power demand from 2016 to 2020

Being one of the most industrial states in India, Gujarat's electricity demand has grown rapidly at a CAGR of $6.1 \%$ annually between FY2008-09 and FY2018-19.Fig.6 shows seasonal variation in Gujarat's Demand for for FY 2018-19.

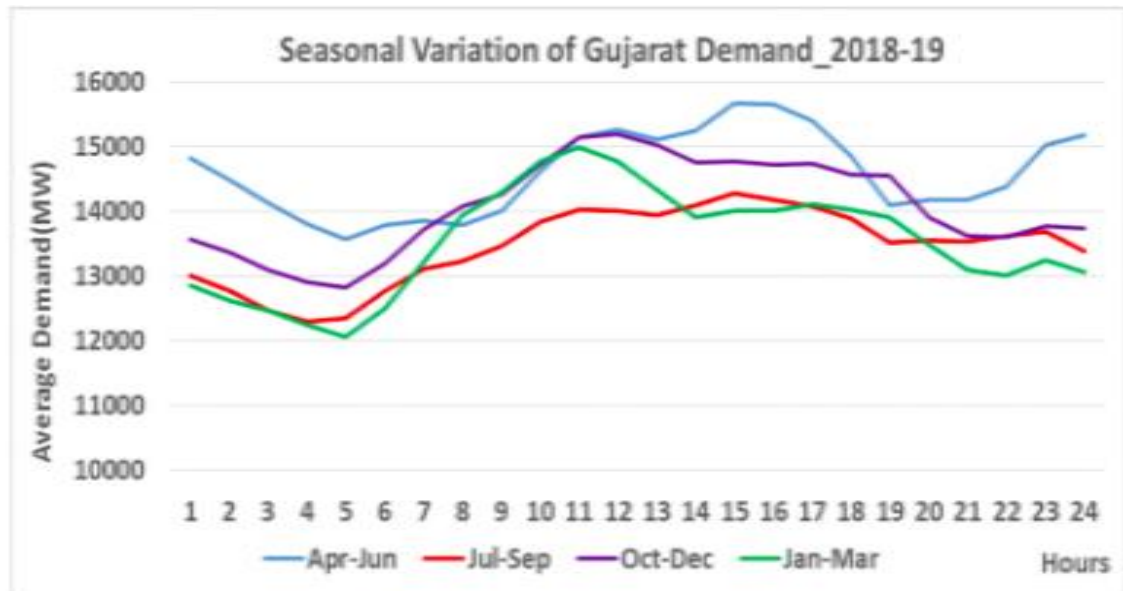

Source: Western Laad Dispatch Centre.

Fig.6.Seasonal variation in Gujarat's demand 
It can be observed that Gujarat's peak demand occurred for three quarters of the year, from July to March, between the hours of 10 a.m. and 2 p.m. Peak demand occurred between 2 and 7 p.m. during the April to June quarter, underlining the importance of planning ahead. And demand side management.

Gujarat has been at the forefront of progress over the past ten years. Utilities in the power industry have fueled socioeconomic development, advancement, and wealth. Gujarat has been in a power surplus since 2009, accounting for roughly $9 \%$ of India's overall energy demand. The state has implemented a number of initiatives that have resulted in increasing private participation in the generation sector and has maintained a steady increase in capacity to meet expanding demand. The following are some of the state-led initiatives to promote the sector

:i. Power generation from Renewable energy sources.

The state has placed a focus on expanding renewable energy generation so that RPO-obligated companies like Discoms may reach their objectives. GERC has established distinct RPO targets in each category to boost solar and non-solar power generation. To encourage the use of solar energy, the state has enacted solar rooftop net metering regulations and solar pump programmes, under which power generated can be utilised for captive consumption and excess power sold to third parties or state distribution corporations.

\section{ii. Energy Efficiency \& Energy Security}

Gujarat is seeing a surge in energy efficiency adoption. GEDA is the MNRE State Nodal Agency and the BEE State Designated Agency. It focuses on the framework for renewable energy and energy conservation policies, as well as their implementation in the state. It also conducts high-quality energy audits of government buildings, such as offices and educational institutions.

The other initiatives adopted are

State has broadened fuel base by adding renewable capacity over last few years.

State is developing gas network \& LNG terminals for improving gas availability.

First state to implement Energy Efficient pump sets in Agriculture sector.

Conducting Energy conservation awareness \& training programs.

Implementing energy efficiency programs like DELP (Domestic Efficient Lighting Program), NSLP (National LED Street Lighting Program), Super-Efficient Fan Program \& PAT scheme in state.

\section{Renewable energy scenario -Wind power Generation, policies adopted by the state.}

Gujarat State has an international border and a shared border with Pakistan on the northwestern outskirts. The two deserts north of Kachchh and between Kachchh and mainland Gujarat are both salty wastelands. Gujarat elevation is a 9 meters height that is equal to 30 feet. Wind resource estimations from the National Renewable Energy Laboratory (NREL) show places with average annual wind speeds of more than $8 \mathrm{~m} / \mathrm{s}$. These places are primarily found in the Gulf of Kutch and along the peninsula's southern coast. The biggest wind energy potential is found in the northwestern section of the state, north of the Gulf of Kutch, according to previous research. The Gulf of Kutch and the southern tip of the peninsula have the highest wind speeds, according to the International Renewable Energy Agency. They also found average wind speeds of $9 \mathrm{~m} / \mathrm{s}$ in the Gulf of Khambhat, which is greater than our estimate. Wind speeds in the Gulf of Khambhat are expected to average $9 \mathrm{~m} / \mathrm{s}$, which is greater than the prediction. The wind speed is strongest in the summer from May to August, with maximum average wind speeds of more than $10 \mathrm{~m} / \mathrm{s}$, notably along the coast lines, according to the regular seasonal cycle that may be expected in India and validation results at five measurement locations. Average wind speeds of less than $7 \mathrm{~m} / \mathrm{s}$ at coastal locations during October and November. 
Gujarat is also one of the top five Indian states for renewable energy, both in terms of current generation capacity and future potential, according to the IEEFA. As of March 2019, there was 2 gigawatts $(\mathrm{GW})$ of solar power capacity, 6 gigawatts $(\mathrm{GW})$ of wind power capacity, and 0.5 gigawatts $(\mathrm{GW})$ of biomass power capacity active. Gujarat's renewable energy potential is estimated to be 72.7 GW by India's Ministry of New and Renewable Energy (MNRE), with solar and wind energy potential equally balanced.

Wind Power Installable Potential as per Wind Atlas 2015 by NIWE[11]

Gujarat has the highest wind power potential in India at 100m Hub Height among all Indian States as follows.

\begin{tabular}{|l|l|l|l|l|}
\hline $\begin{array}{l}\text { Wind Potential @ 100m Hub } \\
\text { Height }\end{array}$ & Rank I & Rank II & Rank III & Total \\
\hline Type of Land & Waste Land & Cultivable Land & Forest Land & \\
\hline Potential in MW & 52288 & 32038 & 105 & 84431 \\
\hline
\end{tabular}

Table .2 Installed Capacity of Wind Farms in Gujarat as of 31/3/2019.

\begin{tabular}{|c|c|c|}
\hline SI.No. & Wind Plants & Installed capacity (MW) \\
\hline 1 & Vershamedi (SUZLON) & 120 \\
\hline 2 & Suthari (SUZLON) & 284 \\
\hline 3 & Sindhodi (SUZLON) & 312 \\
\hline 4 & Vandhiya (VESTAS) & 194 \\
\hline 5 & 132KV Sikharpur (VESTAS) & 90 \\
\hline 6 & 66KV Sikharpur (SUZLON) & 56 \\
\hline 7 & Jangi (SUZLON) & 107 \\
\hline 8 & $\operatorname{Rrb}(\mathrm{RRB})$ & 76 \\
\hline 9 & Veer(VEER) & 55 \\
\hline 10 & Navadra (GEDA) & 27 \\
\hline 11 & Bhogat (GEDA) & 25 \\
\hline 12 & Beta (SUZLON) & 48 \\
\hline 13 & Sadodar (ENERCON) & 462 \\
\hline 14 & $132 \mathrm{KV}$ Enercon (ENERCON) & 180 \\
\hline 15 & Ukharla (SUZLON) & 13 \\
\hline 16 & Gandhvi (SUZLON) & 22 \\
\hline 17 & Baradiya (SUZLON) & 21 \\
\hline 18 & Vasai(SUZLON) & 31 \\
\hline 19 & Kuchhdi(SUZLON) & 30 \\
\hline 20 & Layza(SUZLON) & 38 \\
\hline 21 & Tunkar(SUZLON) & 38 \\
\hline 22 & Jamanwada (SUZLON) & 155 \\
\hline 23 & Tebhda (ENERCON) & 278 \\
\hline 24 & Mota Gunda (ELECON) & 31 \\
\hline 25 & Vinjalpar (ELECON) & 9 \\
\hline 26 & Lamba (GEDA) & 30 \\
\hline 27 & Changdai (SUZLON) & 25 \\
\hline 28 & Vanku(SUZLON) & 50 \\
\hline 29 & $132 \mathrm{KV}$ Mota gunda (SUZLON) & 59 \\
\hline 30 & Sanodar (SUZLON) & 9 \\
\hline 31 & Rajapara (SUZLON) & 50 \\
\hline 32 & Balambha (SUZLON) & 33 \\
\hline 33 & Gorsar(SUZLON) & 26 \\
\hline 34 & Parevada(SUZLON) & 25 \\
\hline
\end{tabular}




\begin{tabular}{|l|l|c|}
\hline 35 & Halenda(SUZLON) & 40 \\
\hline 36 & Rasaliya (ENERCON) & 66 \\
\hline 37 & Kotda Pitha(SH.RAM EPC) & 10 \\
\hline 38 & TITHWA(AZALEA) & 28 \\
\hline 39 & Jasdan Golida(GUJ FLURO) & 70 \\
\hline 40 & 220KV Amarapur (KINTECH) & 08 \\
\hline 41 & Dhank(GEDA) & 25 \\
\hline 42 & Mervadar (GEDA) & 11 \\
\hline 43 & Patelka(GEDA) & 18 \\
\hline 44 & Vadali(ENERCON) & 53 \\
\hline 45 & Rajpara(SUZLON) & 29 \\
\hline & TOTAL & 3382 \\
\hline
\end{tabular}

Gujarat has the highest potential to generate energy from wind; 10,609 MW at 50meter height and 35,071 MW at 80-meter height.Table.2 gives details of some of the wind farms in Gujarat with the installed capacity as of 31/3/2019.Table.3 depict detailed specifications of some of the prominent off shore wind farms in Gujarat.

Table.3 Prominent Wind farms

\begin{tabular}{|l|l|l|l|l|l|}
\hline City & $\begin{array}{l}\text { Wind Farm } \\
\text { Name }\end{array}$ & $\begin{array}{l}\text { Aptitude/ } \\
\text { Depth } \\
(\mathrm{m})\end{array}$ & $\begin{array}{l}\text { No of } \\
\text { Turbines }\end{array}$ & Hub height & $\begin{array}{l}\text { Total Power in } \\
\text { KW }\end{array}$ \\
\hline Bhuj & Jamanwada & 18 & 25 & 90 & 52500 \\
\hline Rajkot & Mahidad-1 & 295 & 12 & 80 & 25200 \\
\hline Rajkot & Mahidad-2 & 295 & 63 & 75 & 50,400 \\
\hline Kutch & Kutch-2 & - & 24 & 90 & 50,400 \\
\hline Kutch & Kutch-3 & - & 50 & 92 & 100,000 \\
\hline
\end{tabular}

Gujarat continues to be the favored location in India for establishing wind generating plants. Gujarat has the highest power generation capacity in the country in 2020-21, despite the problems created by the Covid 19 outbreak [8]. From April 2020 to March 2021, wind power plants with a total generation capacity of 1020.3 MW were constructed and commissioned in Gujarat. This was the single-largest increase in capacity by any state throughout the time period. Tamil Nadu (303.7MW) and Karnataka came in second and third, respectively (148MW). Gujarat took the lion's share of the new wind generating capacity expansion across the country in 2020-21, accounting for 68 percent. According to IWTMA data, about 1,503.3MW of new wind power producing capacity was installed in India in fiscal 2021.

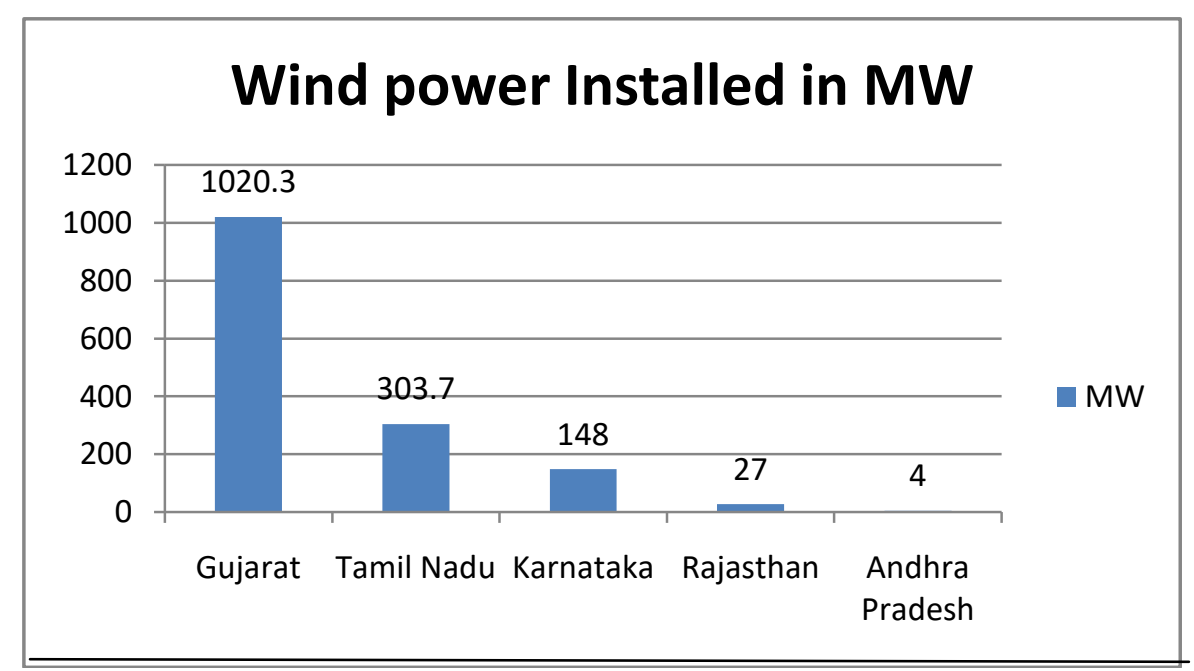

Fig.7. Wind power capacity addition during 2021[8]

Gujarat's current operating capacity for generating power from wind energy sources is 8,561.8MW, up from 7541.5MW in 2019-20, with these new installations. Gujarat also built the 
most wind generating capacity in the preceding fiscal year, with 1,468.4MW.

The majority of the projects that came online in Gujarat last fiscal year with a total capacity of 700MW were auctioned by the Solar Energy Corporation of India (SECI) before to the pandemic's start. Tenders floated by state-run power providers added about 200MW of capacity. In March 2021, renewable energy businesses such as Adani Green and ReNew Power were among the major players that commissioned $100 \mathrm{MW}$ and 300MW wind power projects. Gujarat currently stands second after Tamil Nadu in terms of the total installed wind power generation capacity in the country.

\section{ReNew 300MW wind project in Gujarat[7]}

ReNew Power commissioned a 300-megawatt $(\mathrm{Mw})$ wind project in the Kutch district of Gujarat. The project was executed by ReNew's arm, ReNew Wind Energy (AP2), and has a power-purchase agreement (PPA) with the Solar Energy Corporation of India (SECI) under wind power project bidding tranche-III. With this project, ReNew's total wind energy capacity in Gujarat increased to $950 \mathrm{Mw}$. The project will supply power to districts in Haryana and Odisha at Rs 2.44 per $\mathrm{kWh}$. The commissioning is a significant achievement as it is one of the largest wind farms in the state with 120 turbines and has put in place $73 \mathrm{kms}$ of EHV transmission lines and over $330 \mathrm{kms}$ of medium voltage transmission lines despite major disruptions due to the pandemic.

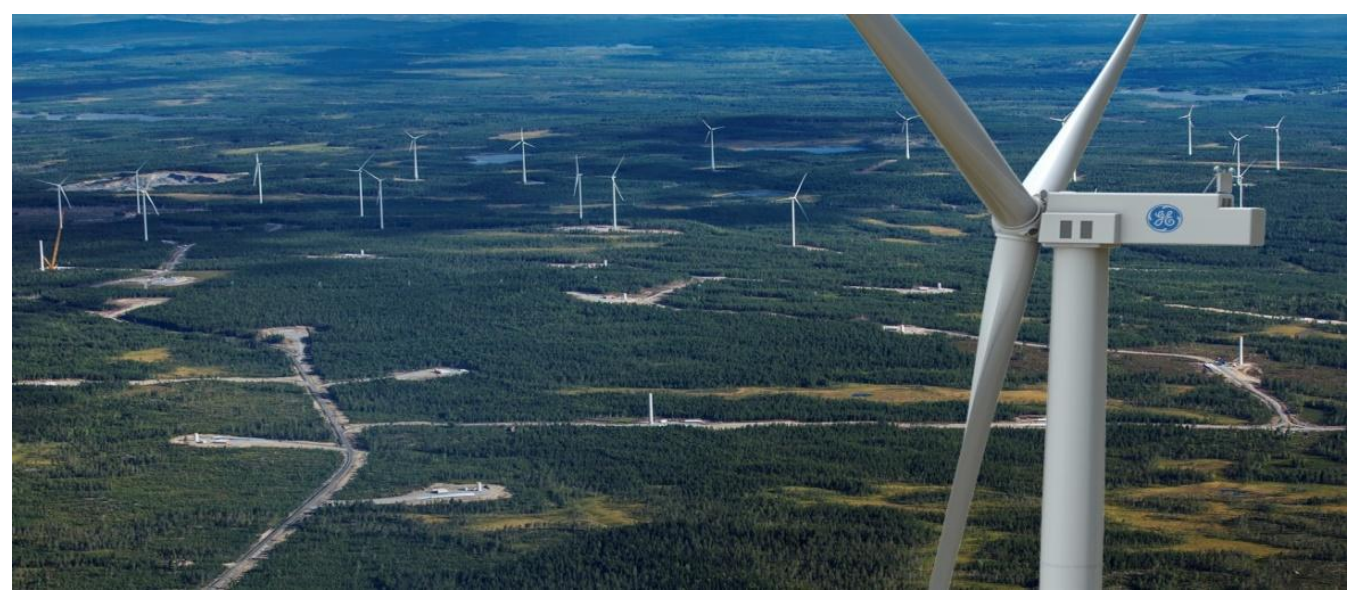

Fig.8.300MW wind farm commissioned at Kutch distinct

\section{Adani green 100MW wind project in Kutch district}

Adani Wind Energy Kutch Three Limited (AWEKTL) has commissioned a 100 megawatt (MW) wind power plant located at Kutch, in Gujarat. With the successful commissioning of this plant, the company has an operational wind generation capacity of $497 \mathrm{MW}$. The commissioning was five months ahead of schedule.

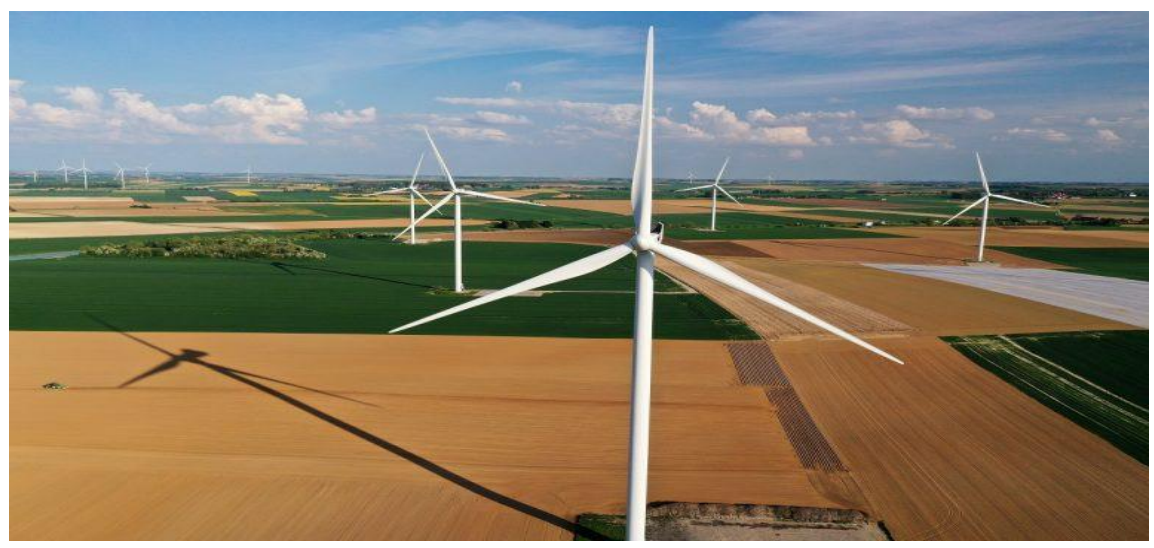

Fig.9.100MW wind farm commissioned at Kutch district 


\section{Offshore Wind energy}

With over 30 gigawatts of installed capacity, India has a lot of expertise with onshore wind turbines. The Government has also agreed to use offshore wind energy as part of its efforts to combat climate change. According to the Indian government, India's offshore wind energy potential is projected to be over 70,000 megawatts (MW), with the most of it located in coastal Gujarat and Tamil Nadu.

The first offshore wind energy project of $1 \mathrm{GW}$ capacity off the coast of Gujarat. The required geophysical study for 365 square $\mathrm{km}$ has already been completed and the geo-technical and metocean studies are under progress. The National Institute of Wind Energy (NIWE) has floated the expression of interest (EoI) for this first offshore wind energy project of India.

With the timely policies adopted by the state government the renewable energy capacity is set to touch 12000MW.

\section{Renewable energy scenario -Solar power Generation, policies adopted by the state.}

Over the next few years, the state has set an ambitious goal of increasing overall energy generation from $15,000 \mathrm{MW}$ to $20,000 \mathrm{MW}$. The state administration has now devised an action plan. The state government has devised a strategy to boost renewable energy's portion of overall energy generation from $10 \%$ to $17 \%$ by 2022 . The government announced in January 2019 that solar power generation would be expanded by 3,000MW per year. In addition to the existing solar power programme, the state has also announced a solar-wind hybrid programme, with the goal of establishing four to five such parks with a total capacity of at least $2000 \mathrm{MW}$.

Gujarat, which has almost 11,000 megawatts of renewable energy installed capacity, has today revealed a new solar policy that aims to increase the state's overall renewable energy capacity to 30,000 megawatts by 2022 .

\section{The key highlights of the solar power policy 2021[9]}

- The programme is notable for the additional flexibility it grants generators, with an emphasis on both the state and producers benefiting from decreased prices.

- Industry could be the big winner, as electricity costs, which are currently around Rs 8 per unit, are expected to drop by half by adopting renewable energy.

- The decision to eliminate the established capacity ceiling is one of the most important points.

- The new regulation also allows consumers to lease their buildings or roofs to third parties for the purpose of constructing plants that generate and consume electricity on the same property. The solar project was formerly limited to $50 \%$ of the sanctioned load or contracted demand.

- A developer's security deposit to a power distribution firm (DISCOM) has been cut from Rs 25 lakh per megawatt hour to Rs 5 lakh per megawatt hour.

- According to the new policy, the state will acquire extra energy from residential and micro, small, and medium-sized business consumers after deducting their usage. This means they'd be able to sell their excess power at a discounted rate.

- Residential users would save between Rs 1.77 and Rs 3.78 per unit, industrial and commercial (captive) would save between Rs 2.92 and Rs 4.32 per unit, and industrial and commercial (third-party sale) would save between Rs 0.91 and Rs 2.30 per unit, according to the policy.

- Discoms will now acquire power from smallscale solar installations under $4 \mathrm{MW}$ with a 20-paise-per-unit premium above the average price.

- At the end of March 2020, Gujarat has the biggest number of subsidised rooftop solar plants in India, with 51,000 subsidised rooftop solar plants in the residential category. In neighboring Maharashtra, for example, the discom and poorly planned incentives have made them practically impossible to implement. 
With the start-up of the enormous $30 \mathrm{GW}$ Kutch project, which is expected to be completed by 2025 , the state appears ready to keep its lead in the renewable energy market.

The Gujarat Energy Development Agency one of the premier organizations has been working in the field of renewable energy development and energy conservation. GEDA was a trailblazer in the creation of a long-term renewable energy policy and the implementation of sustainable energy programmes across the state. The goal of GEDA has been to make renewable energy and energy efficiency technology financially and commercially feasible.

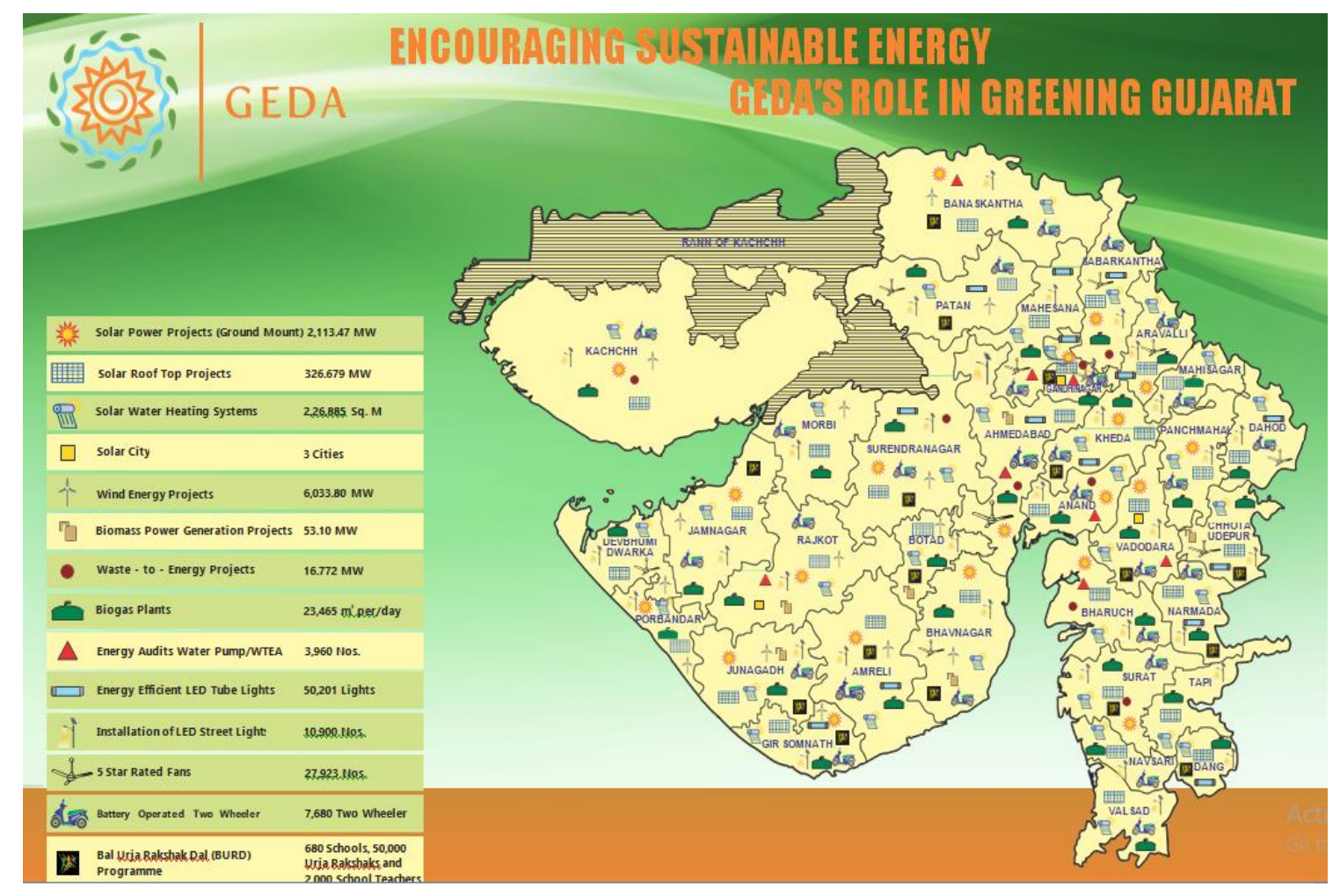

Fig.10.GEDA's Role in greening Gujarat[6]

Gujarat has topped in the installations of solar rooftop systems in the country with 735.18 megawatt (Mw) of solar power generation capacities. The State holds about one-fourth or 24 per cent share in the country's total solar rooftop installations of $3088.74 \mathrm{Mw}$ as on August 31.

Gujarat tops the list of states with the highest installed rooftop solar energy generation capacity in India. It's total rooftop solar capacity as on February 29, 2020, stood at 468.9 megawatts (MW). While its total installed solar power generation capacity stood at 2,886.16 MW at the end of February this year.

Few of the installed roof top solar installations in Gujarat with their specifications are listed in Table. 3 and Fig. 11.

Table.3.Roof top Installations[14]

\begin{tabular}{|l|l|l|l|l|l|}
\hline Location & $\begin{array}{l}\text { Project } \\
\text { Size }\end{array}$ & Roof Type & Module Type & $\begin{array}{l}\text { Annual CO } \\
\text { abation }\end{array}$ & $\begin{array}{l}\text { Commmisioned } \\
\text { on }\end{array}$ \\
\hline Ahmedabad & $416 \mathrm{KWp}$ & RCC & Polycrystalline & 599 tonnes & 2018 \\
\hline Vadodra & $220 \mathrm{KWp}$ & RCC & Polycrystalline & 317 tonnes & 2015 \\
\hline Sanand & $2050 \mathrm{KWp}$ & Metal & Polycrystalline & 2,952 tonnes & 2015 \\
\hline
\end{tabular}




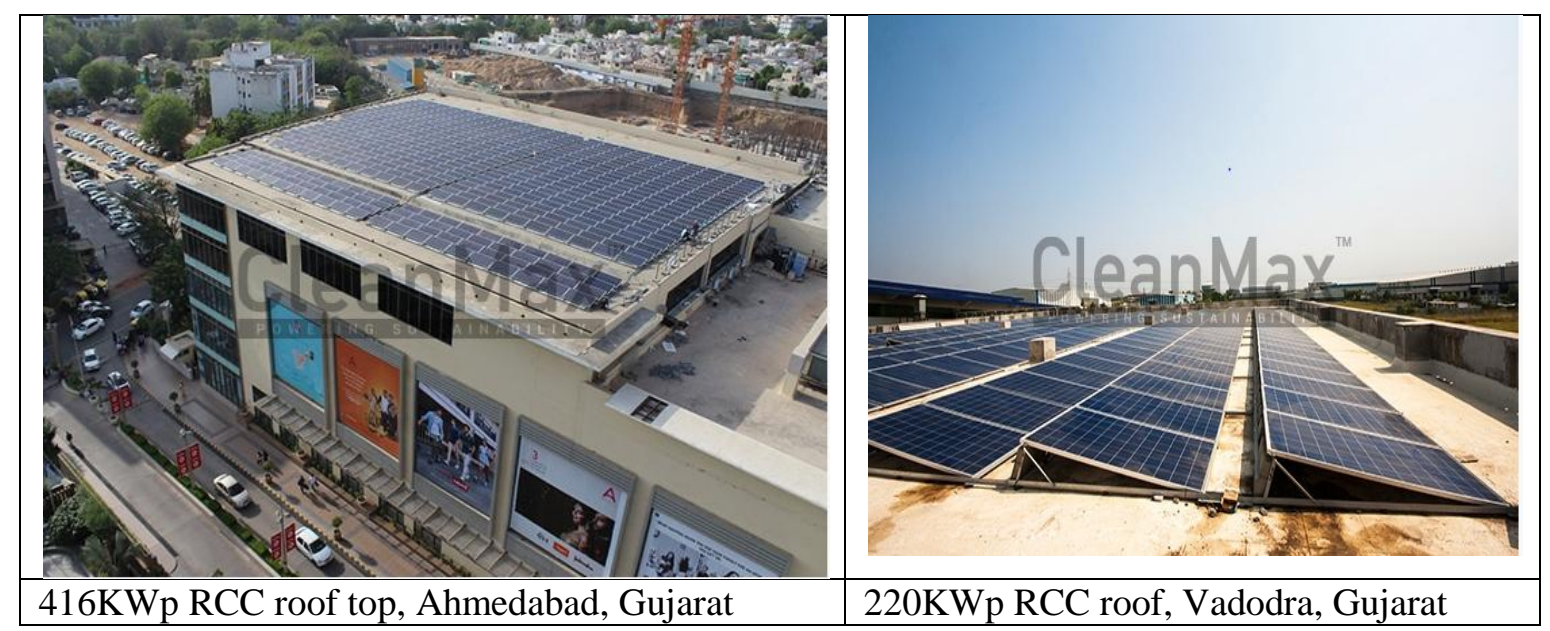

Fig.11.Roof top Installations [14]

\section{Solar Power Plants in Gujarat}

World's largest hybrid solar-wind power park-An area of 72,600 hectares or 726 square kilometers has been set aside for what is being billed as the world's largest hybrid solar-wind power park, around 30 kilometers from the last point accessible to humans in the Rann of Kutch. The sun beats down fiercely in this desolate desert area, where no one lives, and temperatures rise to 35 degrees Celsius during the day. Winds howl unabated across the barren region, making it ideal for the type of setup envisaged by the administration.

The Kutch solar project will take over as the "world's largest" from the 2,000 MW solar park in Pavagada, Karnataka. The Pavagada facility, which began operations in 2018, supplies almost $19 \%$ of the country's solar energy and has a capacity of 27,199 megawatts (MW) by the end of 2018. One megawatt is somewhere between 4,000 and 5,000 units of power. The average Indian home uses 5 units of electricity each day. When completed, this facility will generate 30,000 megawatts of electricity.

150 MW solar power plant in Kutch- Adani Solar Energy Kutch One Limited has completed the commissioning of a $150 \mathrm{MW}$ solar power facility three months ahead of schedule. The completion of this project ahead of schedule is yet another extraordinary achievement accomplished in the midst of Covid-19 and the flood crisis in Kutch, Gujarat.

5GW solar park in Dholera- is a 5GW solar power project being built in two parts near Dholera village, Gujarat, India, around 80 kilometers from Ahmedabad. The solar park is part of the government's intention to build India's first world-class greenfield smart city project, the Dholera smart city, which was unveiled in 2009. The Dholera solar park will be built on type 1B Coastal Regulation Zone (CRZ) land in the Dholera Special Investment Zone, situated along the Gulf of Khambhat region, Gujarat.

\section{Issues and Challenges faced in integration of Renewable energy sources and measures adopted by the State}

Various studies reveal that integrating large-scale renewable energy generation, mostly wind and solar energy, with the grid creates a slew of technological hurdles and concerns in grid operation and management. Most green energy sources depend on natural, uncontrolled recourses such as the sun, wind, or ocean waves[12]. Some of the major issues are

Availability of Power- Power generation based on natural resources that are unmanageable by people is one of the most serious concerns in the field of renewable energy. Solar-powered electricity, for example, is created only when sunlight is available and turns off at night; wind energy, on the other hand, is dependent on wind availability; if the wind speed is very low, the 
turbine will not revolve, resulting in zero power. On the other hand, too much wind can harm the generator, necessitating the maintenance of a careful balance in order to sustain consistent energy generation. Integration is becoming increasingly difficult due to the uncertainty in energy generation in renewable energy technologies.

Power Quality Issues- To ensure network stability and efficiency, consistently excellent power quality is required. The power supply's quality allows the system to operate with high dependability and cheap costs. Poor power quality, on the other hand, can have serious consequences for the power system as well as industrial processes. It has the potential to result in excessive costs and equipment failure. Frequency disorder, voltage/current harmonics, low power factor, voltage variation, and transmission line transits are all examples of power quality issues.

Resource Location- The majority of renewable energy plants that feed into the grid require a lot of space. Renewable energy sources are typically dictated by location, which can be discouraging to users. To begin with, some renewable energy sources are simply unavailable in certain areas. Second, in terms of cost and efficiency, the distance between the renewable energy source and the grid is critical. Furthermore, renewable energy sources are affected by weather, climate, and geographic location, thus one type of energy generation may not be ideal for the region.

Information Barrier- While progress is being made in this area, there is still a dearth of knowledge and understanding about the benefits and necessity of renewable energy. Renewable energy implementation has received investment and capital allowances. Government authorities should clearly help and advice applicants and potential recipients on how to qualify for renewable energy incentives.

Cost Issue- One of the greatest impediments to the development of renewable energy is the high initial cost of installation. Although a coal plant costs roughly $\$ 6$ per megawatt to build, it is well known that wind and solar power plants also cost a lot of money. Furthermore, storage solutions for generated energy are costly and provide a significant obstacle in terms of megawatt generation.

Environmental Issues- This region selected for installation of renewable power projects, for example the $30 \mathrm{GW}$ kutch hybrid project is the home to hundreds of bird species and its adjoining areas are also prime habitat for the vultures and flamingos. There are many studies by reputed institutes like Wildlife Institute of India that have warned against the death of birds due to collisions with power lines.

The effect of these changes is determined by the scale of renewable energy projects, grid capacity, and the voltage level at which the RE project is connected to the grid. There are many technology developments and integration approaches available for grid systems to address technical integration and operational challenges, which, once adopted, would greatly aid in making the grid strong enough to endure the huge variability of renewable energy.[project report].Some of these are

(a) Deployment of synchrophasor technology i.e. PMUs/WAMS

(b) Using STATCOM devices

(c) Development of flexible generation, ancillary services, spinning reserves and Storages

(d) Renewable energy forecasting for proper scheduling

(e) Better demand side management etc.

The Government of Gujarat has framed various power policies in order to overcome the challenges faced in enhancing the power generation using renewable energy sources.

\section{Conclusion}

Harvesting renewable energy and using it into the energy mix is a critical prerequisite for fulfilling rapidly rising energy demands in an environmentally sustainable manner. Because renewable energies are one of the key enablers of the SDGs, increasing their penetration with present power networks is a top priority around the world. India's energy demand is gradually 
increasing as a result of economic expansion and population expansion. By 2030, it would have more than doubled, prompting the Indian government to pursue huge policy and financial steps to gather energy from climate-friendly renewable energy sources.

Gujarat is one of the rising states in renewable power generation and was considered as a case study for this research to evaluate the renewable energy progress contributing to the state's socio-economic development. Gujarat has an enormous renewable energy potential especially wind and solar. The various policies like solar power policy of 2021 has ranked Gujarat as the first state with highest number of roof top installations. The wind power policy has led to development of world's largest hybrid solar-wind power park. The future focus is on offshore wind power plant, g eothermal power plant and tidal power plant.

\section{REFERENCES}

[1] Elavarasan, R., Shafiullah, G., Manoj Kumar, N., \& Padmanaban, S. (2019). A State-ofthe-Art Review on the Drive of Renewables in Gujarat, State of India: Present Situation, Barriers and Future Initiatives. Energies, 13(1), 40. doi: 10.3390/en13010040.

[2] Ghose, D., Pradhan, S., \& Shabbiruddin. (2019). Development of model for assessment of renewable energy sources: a case study on Gujarat, India. International Journal of Ambient Energy, 1-10. doi: 10.1080/01430750.2019.1691650

[3] State load Despatch Centre-Gujarat Electricity Board Annual Report 2019-20. (2020, September). State load dispatch center. https://guvnl.com/annualreports/Final\%20English\%20GUVNL\%20Annual\%20Report\% 2024-02-2021.pdf

[4] Global wind report 2019. (2020, September). https://gwec.net/global-wind-report2019/

[5] C.D.A.P.Z.P. (2014, September). Wind Resource Assessment of Gujarat (India. NREL. https://www.nrel.gov/docs/fy14osti/61741.pdf

[6] GEDA 2019. (2019). [Image]. Retrieved from http://GEDA_Map2019_6x4feet_090719.pdf

[7] Jai, S. (2021). ReNew commissions 300-Mw wind power project in Kutch district of Gujarat. Retrieved 15 June 2021, from https://www.businessstandard.com/article/companies/renew-commissions-300-mw-wind-power-project-inkutch-district-of-gujarat-121032600027_1.html

[8] https://energy.economictimes.indiatimes.com/news/renewable/gujarat-tops-wind-powercapacity-addition-in-2020-21/82566307

[9] https://www.saurenergy.com/solar-energy-news/gujarat-solar-policy-2021-key-points

[10] https://www.saurenergy.com/solar-energy-blog/top-10-rooftop-solar-states-by-installedcapacity-in-india

[11] (2021). Retrieved 15 June 2021, from https://www.indianwindpower.com/pdf/GujaratState-Wind-Power-Profile.pdf

[12] Moradiya, M. (2021). The Challenges Renewable Energy Sources Face. Retrieved 15 June 2021, from https://www.azocleantech.com/article.aspx?ArticleID=836

[13] https://en.wikipedia.org/wiki/Gujarat.

[14] (2021). Retrieved 15 June 2021, from https://www.cleanmax.com/solar-power-plants-ingujarat.php 